\title{
Self-quotations as reinterpretation of the past in the Russian rock band DDT
}

\author{
Sergio Mazzanti \\ University of Macerata \\ sergiomazzanti@gmail.com
}

\begin{abstract}
This article discusses the use of lyrical, musical and visual self-quotations in the works of DDT, one of the most important Russian rock bands. After the collapse of the USSR, the legacy of the Soviet rock movement has been the object of a nostalgic approach, both by its protagonists as individuals and by the society as a whole. Supported by different methodological approaches (Genette 1997; Yurchak 2003, 2005; Boym 2001; Chion 2016; Veselovsky 2006), the author examines how Yury Shevchuk, DDT's leader, uses self-quotation as an artistic tool to re-interpret the past: his own past, and at the same time the past of the country. Self-quotations can also act as a kind of dialogue between the author and society, helping us to understand the role of intertextuality in popular music, and to position it in the cultural field between the individual and the social.
\end{abstract}

KEYWORDS: Russian popular music, palimpsest, nostalgia, self-quotations, appropriation, definition of popular music.

\section{Preface}

The collapse of the USSR in 1991 brought enormous and sudden changes in all spheres of Russian society. It is not easy to give an objective historical reconstruction of Soviet society, even if (or because) relatively little time has passed since its collapse. Especially after significant historical upheavals, people tend to reinterpret the past from the point of view of the present, often without noticing that they are doing so. Alexei Yurchak has shown how representations of the Soviet Union have quite quickly changed in the minds of the Russian people. For example, he argues, "diaries from Brezhnev's period, produced during the 1970s, and memoirs produced retrospectively in the 1990s are not only written in two distinct voices and languages; they also evaluate the everyday realities of Soviet socialism, both implicitly and explicitly, in two different ways" (Yurchak 2005: 6). The duality 
between the past and its representation in the present is what Svetlana Boym (2001) calls "nostalgia", defined "as a longing for a home that no longer exists or has never existed" (ibid.: xiii). For many Russian people, this lost home, real or imagined, at least partially coincides with the Soviet rock movement, which from the sixties became a considerable part of Soviet youth culture.

In this article (1) I will show this process of reinterpretation through the songs of Yury Shevchuk, leader of DDT, one of the most important Russian rock bands. Here I use the generic term Russian rock, as rock music in Russia and in the Russian language, instead of Russkii rok which, as shown below, has a very specific and historically determined meaning. In particular, I will discuss how Shevchuk used (and still uses), in new songs, more or less explicit references to his own earlier songs; this interesting artistic tool, that I call "self-quotation", allows him to reinterpret his own past and, especially, the role of his group in Soviet rock'n'roll. This case-study can also help us to understand the role of rock music in 21 st century Russia, since its representation, as we will see, is partially based on Shevchuk's songs. More broadly, it can also give some theoretical elements to approach the role of intertextuality in popular music.

\section{Methodological Introduction}

Self-quotation (2), being a specific type of quotation, can be analyzed through the theory of intertextuality. This term is usually ascribed to Julia Kristeva, who observed that "any text is constructed as a mosaic of quotations; any text is the absorption and transformation of another" (see Burns and Lacasse 2018: 61). This idea has been developed by Gerard Genette in his theory of the palimpsest, where he defines transtextuality as any "relationship uniting a text B ([...] the hypertext) to an earlier text A ([...] the hypotext)" (1997: 5). In this article I will use only one of Genette's five possible types of transtextuality, that is, transtextuality in the most restricted sense, "as a relationship of copresence between two texts or among several texts: that is to say, eidetically and typically as the actual presence of one text within another" (ibid.: 1-2). This kind of explicit quotation creates an easily recognizable link to the past, providing unmistakable proof of a direct relationship between two texts, preventing arbitrary interpretations and showing a safer way for detecting less evident references.

The recently published collection of articles entitled The Pop Palimpsest: Intertextuality in Recorded Popular Music is mostly based on Genette's conception, especially the first and most theoretical chapter, Serge Lacasse's "Toward a Model of Transphonography" (Burns and Lacasse 2018: 9-60). In the introduction, the book editors Burns and Lacasse argue that "popular music is undoubtedly a multilayered palimpsest" (ibid.: 1). If "musical intertextuality is (...) a network of songs, styles, artists, and consumers influenced, directly or indirectly, by the music and artists that came before", it can be said that "popular music is intertextual" (ibid.: 4). Starting from Lacasse's conception of transphonography, the book shows many cases of intertextuality in popular music: for example, hyperphonography, the "transformation of existing songs and recording" (ibid.: 18), and polyphonography, compilations, albums, mix tapes, digital playlists, deejaying, and so on (ibid.: 24). The latter category, especially, is very common in popular music; just think about collections and greatest hits albums, where earlier songs are re-released, giving them the status of "classics", but also live albums, almost always made of new performances of previously released studio songs (see Mazzanti 2014). It must be added that polyphonography cannot be considered a proper case 
of quotation, since the hypotext is fully or almost fully inserted in the new context and does not lose its integrity, while proper quotations use only a part of the hypotext, becoming part of the hypertext. Another useful category in Lacasse's application of Genette's palimpsest concept is extraphonographic practices, such as "cover illustrations, album reviews, liner notes, videos" (ibid.: 31). Music videos also became a fundamental tool for shaping the image of groups and singers (see for example Vernallis 2004). Music, song lyrics, and video images can refer to one another in different ways. I will refer to audio-visual theory, namely Michel Chion's (2016: 162) concept of point of synchronization, as "a particularly salient instant of synchronous encounter between concomitant sonic and visual moments or, to put it in somewhat different terms, a moment wherein the effect of synchresis is particularly marked and emphasized"; this concept will be used in the article in order to discuss the possible intersections between music, words, and images.

Unfortunately, no definition of popular music is provided in The Pop Palimpsest, neither is popular music compared, for example, to art music or folk music. It is not clear in the book whether popular music should be considered more or less intertextual than other forms of music. In order to understand the specificity of popular music with respect to intertextuality, I think it is unavoidable to define better what we mean by "popular music". I provide below a new definition of this concept, that will help as well, I hope, to outline how Shevchuk's poetics refer to both popular and art musics.

It must be said that the practice of auto-citation is widespread in all fields of culture, for example in literature from ancient and medieval periods (Dante for example) to postmodernist writers. Self-quotations are also common in classical music. Austin and Tayeb, studying Berlioz's compositions, state that "composers through the ages have not infrequently borrowed from themselves: music written or sketched earlier is re-used for later works, and often adapted in the process (...). There is of course nothing reprehensible with the practice: composers are free to do what they like with their own music" (Austin and Tayeb 2008).

Self-quotations are, of course, present also in popular music, especially in its more art-like expressions, such as jazz and progressive rock (Middleton 1990: 221 2), but also in other genres (hip-hop, for example, "was founded on the manipulation of pre-existing material", according to Williams 2013: 1). Limiting myself to examples preceding or contemporary to the songs I will discuss, the Beatles provide many examples of self-quotation, as in "All You Need is Love" (Parlophone 1967) ending with small fragments of "Yesterday" and "She Loves You", or in "Glass Onion" (Apple 1968), referring to "I Am The Walrus", "Strawberry Fields Forever" and other Beatles' songs (see Beatles Bible). As an example of visual self-quotations, we can mention the music video of The Rolling Stones" "Don't Stop" (Rolling Stones/Virgin 2002), scattered with references to their songs (Laffranchi 2002), or Queen's "The Show Must Go On" (Parlophone 1991), completely composed of fragments from the band's previous clips and concerts.

In popular music studies, it has been noted that self-quotations can perform different functions: polemics directed towards listeners or journalists, nostalgia, irony, and so on. As the English musician and composer Christopher Howell (1997) puts it, "self-quotation at its best (...) can serve to clarify the composer's message and deepen the listener's perception of it". Artists, in other words, can use elements of their previous works in new ones, when they feel that the audience didn't understand what they wanted to communicate; but self-quotations can also be a kind of self-reflection, a way to express a new interpretation of the past and offer it to listeners. Often, as discussed later, self-quotations are used in both these ways, 
creating a dialogue between the authors and themselves (in the past) and between the authors and their audience (in the present).

Since self-quotations explicitly and consciously refer to the artist's previous experience and works, they can be considered as an expression of a retrospective glance to the past, and can therefore in many cases interpreted as a case of nostalgia. In her work on the subject, Boym (2001) introduces a distinction between restorative nostalgia, as "a transhistorical reconstruction of the lost home" (ibid.: XVIII), and reflective nostalgia, focused "on the meditation on history and passage of time" (ibid.: 49). The boundaries between the two categories do not appear always clear in Boym's perspective, and they "might overlap in their frames of reference", as the author herself admits (ibid.). In some passages, she seems to approach them rather more as an ethical distinction between "bad" and "good" nostalgia, than as epistemically objective categories. But inside the book, other elements can be found making a slightly different distinction between the two nostalgias, more appropriate for the purposes of this article. First, Boym considers nostalgia as a historically delimited phenomenon: "Nostalgia was a historical emotion, and we would do well to pursue its historical rather than psychological genesis. (...) Nostalgia was diagnosed at a time when art and science had not yet entirely severed their umbilical ties" (ibid.: 7). Since personal experience cannot be separated from the social environment in which it grew, "nostalgia remains an intermediary between collective and individual memory" (ibid.: 54). Since restorative nostalgia seems to be more related to collective memory, while reflective nostalgia refers mostly to individual experience (ibid.: XVIII), we can go further than Boym's conception and consider the two types of nostalgia as the two poles of the opposition "collective vs individual".

This opposition brings us to the concept of "historical poetics", framed by the 19th century Russian scholar Alexander Veselovsky as the study of the role of tradition in individual creativity (2006: 537). In my 2017 paper at the biennial IASPM conference in Kassel (let me cite myself in an article about self-quotations), I used Veselovsky's approach to propose a definition of popular music as "repopularized music in an individualized society". In my approach, the idea of the "popular" can be interpreted through the opposition between the collective and the individual, folk music being more focused on the first pole of the opposition, art music on the second. From this point of view, popular music can be understood as the field of intersection between classical and folk music, since it draws both from the collective and the individual. If we consider a higher and higher individualization as a typical character of modern societies, popular music can be viewed as the result of the modern people's increasing lack of collective experiences. Self-quotation's double function fits quite well with this interpretation of popular music, as we will see in the following analysis and the final discussion (for a larger and more accurate discussion of my definition of popular music, see Mazzanti 2019).

\section{Soviet rock and DDT}

It is undoubtable that the appearance of rock'n'roll in the USSR was a real revelation for young people as, indeed, it was in many other countries. During the Cold War, in Western countries the interpretation of Soviet rock music exclusively as political dissidence against the regime prevailed (see for example Ryback 1990), fuelled by political considerations rather than by a serious approach from inside. The Soviet rock journalist Artemy Troitsky (1987) began to break down this partial and 
simplistic point of view, presenting Soviet rock as a phenomenon more widespread and complex than political dissidence. But it was not until the new century that a completely new and scholarly approach to the subject appeared. Alexei Yurchak (2003; 2005) gave a different picture of the "last Soviet generation", less marked by the dichotomy of "dissidence versus socialist regime": the collapse of the USSR was prepared by quite a long period during which "it was increasingly more important to reproduce precise ideological forms than to adhere to the precise meanings these forms were supposed to convey" (idem 2003: 504). This process of reinterpretation even allowed for the insertion into the frame of communist ideology of a phenomenon such as rock music. Thanks to this new approach, and with the development of popular music studies (for example, the journal Popular Music and the creation of the academic organization IASPM), some scholarly work appeared with a less politicized approach to songs, where not only contextual aspects were considered, such as society and politics, but also music and lyrics. In the field of Soviet and post-Soviet popular music, the best example is probably Yngvar Steinholt's Rock in the Reservation: Songs from the Leningrad Rock Club 1981-86, which deals mostly with the eighties but also gives a brief, but quite exhaustive, account of the earlier history of Russian rock (Steinholt 2005: 15-33; see also the recently published collection of articles Youth and Rock in the Soviet Bloc: Rish 2015).

In post-Soviet Russia, the main scholarly approach to popular music is represented by the collection of works entitled Russkaia rok-poeziia: tekst $i$ kontekst ("Russian Rock-Poetry: Text and Context"), published almost every year by the university of Tver' (first issue in 1998). As the main editor Yu.V. Domansky admits, these publications focused from the beginning on the verbal element of "rock poetry", almost ignoring the musical component. In later issues, other aspects of popular songs began to be considered, but music itself still looks to be the most neglected aspect (see Domansky 2013). Unfortunately, the achievements of popular music studies are almost completely neglected by Russian contemporary musicologists (IASPM is not present in Russia).

Soviet rock developed progressively, and was characterized by many different nuances in space and time. The maturity of Soviet rock can be considered as the time when musicians moved from translation to appropriation, that is, when they began to compose in their own language rather than just reproducing Western models. In this later phase, two macro periods can be outlined: the first generation developed in the 1970s, while the second mainly refers to the 1980s. The rock critic and composer II'ia Kormil'tsev, in an article co-written with Ol'ga Surova, describes this generational shift as the passage from a subculture to a counterculture in the years between 1986 and 1987, at the beginning of perestroika (the attempt of Mikhail Gorbachev, the last head of the USSR government, to reform the socialist state through some liberal changes). With respect to the passive, escapist approach of older rockers, the main distinguishing feature of the second generation was a war-like, aggressive stance (Kormil'tsev and Surova 1998: 25). In this period, rock began to be characterized as the expression of social and political issues.

It is interesting to note that the years between 1982 and 1985 were probably the worst period for the rock movement in the USSR: as Steinholt puts it, there was a "massive anti-rock campaign, the final and perhaps most aggressive repression programme launched against rock in the Soviet era" (2005: 33). Until then, Soviet authorities had not openly acted against the rock mania, limiting their intervention to a contemptuous silence or trying to control it. In 1981, the Leningrad rock community was even able to open an officially recognized rock club, although not 
without the intervention of the KGB (the USSR's main security agency). The new politics of the government towards the rock movement after 1982 was one of the main reasons for the clash between the two generations. 1970s groups such as Mashina Vremeni and Akvarium, feeling themselves separate from the society, accepted remaining enclosed in the Rock Club as in a "cultural reservation" (ibid.: 37 ), just to have the possibility of making their music. Younger rockers, on the other hand, preferred to express themselves free from any political and psychological censorship, even if it meant facing the hostility of the authorities.

In the late 1980s, during perestroika, Soviet rockers took advantage of the new situation to fill up stadiums with fans who found in rock and roll the best embodiment of the wide-spread discontent towards socialist government and the hypocrisy of the party's rhetoric. The young rock generation generally had a very negative attitude towards perestroika, and considered it another attempt to resurrect an oppressive system (see Mazzanti 2011); quite paradoxically, the most liberal period of Soviet government happened to coincide with the most anti-government years of the rock movement.

Yury Shevchuk, with his group DDT (3), is one of the best examples of the second generation of Soviet rock, probably its most representative symbol. Many consider him the "flag of Russian rock" (4) (see Nebudnii chas 2000: 03:17), or even the "last knight of rock \& roll" (Kozitskaia 2001: 188). An overview of DDT's discography and Shevchuk's poetics can help us understand why, and when, this sort of canonization happened.

In almost 40 years of activity, the rock band DDT (founded in 1980 in Ufa, capital of the Soviet republic of Bashkiria) released 21 albums and hundreds of songs. It is not always easy to unequivocally distinguish DDT's studio albums from collections and live albums. I included one fully live and one half-live album in DDT's discography (see Table 1), since some songs exist only on these albums, and the group have always considered them equivalent to their fully studio albums. It must me added that distinctions between date of recording, publication, and release are also very nebulous, due to the particular socio-political situation in the Soviet Union and, partially, in the first post-Soviet years. Nikolai Kharitonov, the author of the most complete biography of Shevchuk, divides his production into three periods: A) the Ufa period, until about 1986; B) the first Petersburg period, until 1991, and; C) the second Petersburg period, until the year of publication of the book (Kharitonov 1998). If we add the 2000s as a fourth period (D), this chronological scheme almost fully corresponds to the political changes that affected and interacted with the singer's personal biography, respectively: A) late Brezhnev, Andropov and Chernenko; B) Gorbachev; C) Yeltsin, and; D) Putin. Chronological proximity does not allow a division of the last two decades, though in the last years Shevchuk's poetics changed further. I have thus analyzed his production only until the middle of the 2000s (more recent songs are only mentioned briefly at the end of the article).

In the first of DDT's albums, Svin'ya na raduge ("Pig in the Rainbow", 1982), socio-political issues are limited to the discontent of youth and a subtle irony towards society, mixed with a typically Russian melancholia. The group was even awarded with the Golden Tuning Fork, a prize awarded to the best patriotic Soviet song, for the pacifist hymn "Ne streliai!" ("Don't Shoot!"). One of the first songs of the group's earlier period is "Dozhd"" ("Rain", 1981), a melancholic and poetic hymn to nature and the first thunder, announcing the arrival of Spring. Slavic studies scholar Michael Schieder underlines the presence of "so-called programmatic figures of speech, that the author calls leitmotivs. These are the lexemes VESNA and DOZHD' ("spring" and "rain"). VESNA is the symbol of the beginning of a new time 
in Russia, related with the hope for a free life. DOZHD' becomes in Shevchuk the symbol of renewal, purification and joyfulness of life" (Schieder 2000: 108). This is, as I will discuss later, rather truer for the new version of the song, released in 1992, than for the first version.

TABLE 1. DDT'S Discography.

\begin{tabular}{|l|l|l|}
\hline ALBUM & $\begin{array}{l}\text { YEAR } \\
\text { (first publ.) }\end{array}$ & $\begin{array}{l}\text { Label } \\
\text { (first official release) }\end{array}$ \\
\hline Svin'ya na raduge & 1982 & DDT Records (1996) \\
\hline Kompromiss & 1983 & DDT Records (1997) \\
\hline Periferiia & 1984 & DDT Records (1996) \\
\hline Vremia & 1985 & DDT Records (1997) \\
\hline Ia poluchil etu rol' & 1989 & Melodia (1989) \\
\hline Ottepel' & $1990 / 1$ & DDT Records (1993) \\
\hline Plastun & 1991 & DDT Records (1995) \\
\hline Aktrisa Vesna & 1992 & DDT Records \\
\hline Chernyi Pes Peterburg & 1993 & DDT Records \\
\hline Eto vse & 1994 & DDT Records (1995) \\
\hline Liubov' & 1996 & DDT Records \\
\hline Rozhdennyi v SSSR & 1997 & DDT Records \\
\hline Mir nomer Nol' & 1999 & REAL Records \\
\hline Metel' avgusta & 2000 & Grand Records \\
\hline Edinochestvo I. & 2002 & REAL Records \\
\hline Edinochestvo Il. Zhivoi & 2003 & REAL Records \\
\hline Propavshii bez vesti & 2005 & CD Land Records \\
\hline Prekrasnaia Liubov' & 2007 & Navigator Records \\
\hline Inache/P.S. & 2011 & Navigator Records \\
\hline Prozrachnyi & 2014 & Navigator Records \\
\hline Galia khodi & 2018 & Navigator Records \\
\hline
\end{tabular}

Only with the second album Kompromiss (1983; DDT Records 1997), and especially with the third Periferiia (1984; DDT Records 1996) and the fourth Vremia ("Time", 1985; DDT Records 1997), did DDT begin to acquire a more politically engaged direction. It is symptomatic of this new engagement that members of the Bashkirian political sphere, who appreciated the "freshness" and "sincerity" of "Dozhd"" (see Arbuzov 1985), strongly attacked Shevchuk's new songs for their alleged anti-social meaning, though more probably because they mocked the local establishment. "Ia poluchil etu rol"" ("I Got this Role", Melodia 1989), the most famous song in Shevchuk's first period, focused on the generational clash: 
So we ask our fathers, but righteous speeches bring no relief.

Can't put together a partial answer with these second-hand phrases.

Their difficult adolescence had passed far away from all things,

All these things that have filled us so completely.

And when we want so badly to scream, loud and long,

All our extensive relations are begging us to stay quiet.

And often, no longer trusting in shabby old gods,

Sons buy drink with the trophies of their dutiful fathers.

Refrain: I got this role,

I got the lucky ticket.

(russmuss.net/song/3669, translation by Ana).

The rock journalist Radoslav Shishov described the subject of the song as being how Shevchuk presents "the feeling of himself as one of the participants of the time, able not only to sing about this time, but also to fight with everything" (Shishov 1989). The "role" the singer has received is to shout for freedom, expressing the generational need of something worth fighting for, in order to create, in Yurchak's words, a "free space to be extended through struggle" (2005: 6).

This "struggle" is also the main subject of the song "Poet" (1985). As the literary critic Viktoriia Mikhailova (2000: 112) states, in Shevchuk's conception the poet's aim is "to transgress the usual, settled lifestyle, to disturb bourgeois, stagnant happiness, which they cannot defend: they just cry for what is gone. But 'our time doesn't tolerate runny noses'. A tough time, requiring action, swift, bold solutions, the time of young people". The song lyrics describe the rock singer, struggling against lies, against destiny, even against the universe. Shevchuk's rock-poet is a poet-fighter, who "will cut through a channel to art" (translation in russmus.net/song/3728).

The album Vremia was recorded in Moscow, where Shevchuk lived before moving definitely to Leningrad (formerly St. Petersburg, capital of the old Russian Empire), both avoiding the increasing pressure of the local KGB (see Kharitonov 1998: 55-9) and looking for a larger audience and a more developed rock community. The first Bashkirian period of DDT's history acted in some manner as a hypotext already by the late eighties, through a kind of recontextualization. The first album of the Leningrad period, la poluchil etu rol' (1989), partially consists of previously released songs ("Ne streliai" had even been released two times). The practice of re-releasing songs, very common in the years of perestroika, was mainly due to practical reasons: the more relaxed political situation allowed rock musicians to record their performances in better studios with better sound. But, some groups took the opportunity to rearrange their songs, sometimes giving them a more or less evident new interpretation. Shevchuk's decision to give to the first of DDT's Leningrad albums the name of their most critical song was, of course, a very clear calling card for the audience of the capital.

\section{The nineties}

With the collapse of the USSR in 1991, the rock movement in Russia suffered a strong identity crisis. The new socio-economic situation put the rockers, who until then had been united by the perception of a shared community, in competition with each other for audience support. In an interview for the political journal Argumenty 
i fakty ("Arguments and Facts") in 2003, Konstantin Kinchev, the leader of the rock band Alisa, described the situation:

$[R]$ ockers differ from all other persons of the Soviet period in that they took upon the courage to sing and say what the rest of the nation was thinking. There was hence a feeling of unity. We were in prominence and therefore it seemed that we were a solid monolith in opposition to totalitarian evil. But the regime collapsed, another one came up. And everyone began to choose his freedom and to defend his understanding of freedom. (Polupanov 2003).

The loss of their social role pushed the musicians to look for new creative paths, and to achieve an artistic maturity; the economic crisis of the 1990s coincided with probably the most creative and artistically interesting period of rock in Russia, with many excellent albums being released during this time. According to my informant Evgenii (personal communication 2000), 1993 was a particularly fruitful year, with the release of Alisa's Dlia Tekh, Kto Svalilsia s Luny (Moroz Records 1993), Brigada S' Reki (FeeLee Records 1993), Chai-f's Deti gor (SNC 1993) and DDT's Chernyi pes Peterburg ("Black Dog Petersburg", DDT Records 1993), among others.

For the new Russia, the first problem to be faced was the transition to a new society. For the rock community, this meant having to define itself in relation to Soviet rock. As I have shown elsewhere (Mazzanti 2007), in the nineties rock musicians and authors mostly referred to the past of the rock movement as "rock'n'roll" or simply "rok", without any ethnic attribute. Up until 1995, the locution russkii rok ("Russian rock") never appeared in any song of the main protagonists of the rock movement, with only one exception: DDT's "Oni igraiut zhestkii rok" ("They Play Hard Rock", 1983), from the album Kompromiss, ends with the words: "Above our Northern Palmyra Russian rock will rise". Even if not very popular, the song has been quoted several times in rok-samizdat (home-made publications released in the USSR without official permission), especially by the influential and politically engaged rock critic II'ia Smirnov, who tried to underline the national element in rock (see Smirnov 1994). It is interesting to note that in the nineties, many rockers referred in their songs to the expression "russkii rok" ironically or even negatively (Akvarium, Tarakany, Mashina Vremeni, etc.). In Nautilus Pompilius' song "Russkii rok" (1996), DDT's "Oni igraiut zhestkii rok" is explicitly quoted and mocked, using both musical and verbal elements (see Mazzanti 2007: 293).

Shevchuk expressed his reflection on these epochal changes already in his first album of DDT's third period, Aktrisa vesna ("Actress Spring", DDT Records 1992), partially inspired by Shevchuk's wife El'mira, who was an actress. The song "V posledniuiu osen'" ("In the Last Autumn"), which became almost an anthem of the post-Soviet rock movement, compares the last autumn of rock' $n^{\prime}$ roll with the last autumn of Aleksandr Pushkin before he died in a duel (in 1837).

The opening track of the album is a new version of "Dozhd", with slightly different lyrics and a completely new musical arrangement, so we can refer to this recording as the hypertext of the earlier version. The palimpsest is complicated by the interaction with the music video, which provides a new interpretation of the song. Shevchuk has always paid particular attention to the development of media and technologies, and to the possibilities of using them for artistic purposes. He was one of the first musicians in Russia to make extensive use of music videos (before perestroika they were almost inaccessible to rockers). In a 2006 press conference (Kazan' 2006) Shevchuk explained how DDT's music videos are the result of a long 
collective process, in which the director and the assistants cooperate with the ideas of the musicians (see, for example, Kharitonov's discussion on the video of "Liubov"; 1998: 138). Shevchuk's lyrics are often very complex and hermetic, and he can use music videos to explain the meaning of his songs and sometimes to reinterpret them.

The first version of "Dozhd" was a melancholic romance, with the voice singing the four couplets with a consistent intonation and a quite simple and relaxed accompaniment, with a gradual increase in intensity. The song ends almost suddenly after the last word, with a short piano coda very similar to the beginning. The 1992 version is accompanied by a video which shows alternately a white hand building a toy town and Shevchuk singing and playing guitar (instead of the piano of the 1981 song). The entry of the rhythm section is synchronized with the first line of the second verse (on the word grom, "thunder"). During the second verse, the town becomes progressively more and more chaotic, while the music gets richer. At the beginning of the third verse, the music gets slower and more intimate, in synchronization with the lyrics ("Tears on the face") and the video (a doll with a flower in her hair). During the instrumental passage after the third verse, tanks and cavalry appear, occupying the town and destroying everything. The fourth and last verse is reinforced by a crescendo in both the instrumental part and the voice, with the first line sung very loud and a fifth higher (unlike the previous verses, and unlike the 1981 version). After the words "And I imagined: the town was flooded by cheerful people. / Everybody went out in the rain", a wave of water invades the toy city and sweeps away everything, with an evident synchronization between words and images. The last instrumental passage of the song is much longer (50 seconds) and more complex than in the hypotext, and progressively decreases in intensity. In the meantime, the video shows the singer putting a small house onto the table and looking at it melancholically, as if he was waiting for a new town to appear. As we see, through the music video and the new arrangement, Shevchuk gives his old song new meanings: the only way to get through the post-Soviet crisis is to start all over again, as nature does every year.

We find a similar gap between the video and the literal meaning of the lyrics in the song "Chto takoe osen"" ("What Autumn Is"), from the same album. The images alternate Shevchuk, alone in a room, with three 1980 rock-movement protagonists - Konstantin Kinchev (Alisa), Viacheslav Butusov (Nautilus Pompilius) and the singer himself - walking in a park and having fun together, chatting on a bench and playing with the yellow leaves. The music video creates a link between personal memories, used as a metonymy of the past of the rock movement, and the lyrics, providing an additional meaning to the song, which is all about natural elements with no explicit reference to either the past or to the rock movement.

The end of rock movement acquired a tragic meaning in Shevchuk's personal experience when he lost his wife in March 1992, two months after she was diagnosed with cancer. The next album, Chernyi pes Peterburg, expresses this gloomy, at times even apocalyptic mood through both the music and the lyrics: cf. the songs "Styx" (i.e. the river of the Underworld), "Beda" ("Sorrow"), "la ostanovil vremia" ("I Stopped the Time"), and others. DDT's leader would later comment on this personal and epochal change:

The whole 1991, when black shadows began to creep along our streets, we tried to write down everything that was written before the nineties. That is, the album Plastun... all these songs... It was in that dull situation, just before the putsch. I wrote vocals in Moscow, the heat was creepy, no wind... Such an absolutely sick, filthy feeling. I did not like the album at all. Then (...) something 
broke forth, it became a little easier... I was kind of bringing out the eighties then. There was a feeling of farewell to the old. I clearly realized that we had to play and do something different. Absolutely different. Otherwise, either we die, or stop, we must move onto other businesses. We looked attentively at each other, at our music, we completely didn't like it anymore. We even decided to not release this album, which was squeezed out for a year. It was simply embarrassing. We released it later, when these sharpened feelings were gone. And we began to reorganize, to reorient ourselves. (Dolgov 2002).

For Shevchuk, the 1990s are the time of the search for a way out of crisis; the crisis of rock'n'roll, the crisis of Russia, and his personal crisis. However, even if Shevchuk was looking for something new, he did not stop looking back to his past. The next album, Eto vse ("That's AlI", DDT Records 1994), ends with the eponymous song, a sort of artistic testament, that DDT for many years has been using as the last song of their concerts. The album Rozhdennyi $v$ SSSR ("Born in USSR", DDT Records 1997) creates an explicit link between the Soviet Union and the new Russia; half of the album was recorded at a 1994 concert, and the last track of the first side, "Blok rok-n-rollov" ("Block of Rock'n'Rolls"), is a medley of old songs, mostly about Soviet rock. However, this is the only case from the nineties in which DDT recontextualizes old songs, and I could not find any proper selfquotation in this period. As we will see, this will become a particular artistic tool of Shevchuk in the next period, by the end of the decade.

\section{The Two-Thousands}

The 1990s were a very critical time for post-Soviet Russia. The sudden introduction of a liberal economic system brought an incredible social and economic crisis. The country found itself at the mercy of criminality, the mafia, and oligarchy, and between 1992 and 1998 the rouble lost up to 40,000 times its value related to the American Dollar (see RUsskii PORtal). Compared to this situation, Soviet times began to appear to have been not so bad, especially the years before perestroika; the dissatisfaction with the capitalistic system grew, together with a nostalgia for the role the USSR had played during the Cold War. At the same time, the perception of the multinational composition of the Soviet Union got blurred, making way for an increase of nationalistic feeling. Putin's governing years (from 1999) are characterized by all these elements, in a particular mixture of change and continuity (as, for example, in the reintroduction of the Soviet anthem, with new words composed by the same musician; see Banerji 2008: 274-5).

The Russian rock movement followed a similar process of nostalgia, intended as reinterpretation of the past, underlining both the national element and the struggle against the Soviet government. The short period of repression between 1982 and 1985 shaped the image of russkii rok in the Soviet Union as a dissident movement. This interpretation spread widely, fuelled by the black-and-white worldview that prevailed at the time of the iron curtain, and political engagement began to be perceived as a distinctive, constitutive feature of the whole Soviet rock movement (see Mazzanti 2007). The collection of greatest hits albums "Legendy russkogo roka" ("The Legends of Russian Rock"), first released in 1996, and especially the radio station "Nashe radio" ("Our Radio"), founded in 1998, helped to create a canon of rock groups, with the implicit suggestion that these should be imitated in order to compose new russkii rok songs. 
The beginning of the Putin era, and the process of the mythologization of Soviet rock, coincide with a shift in DDT's history, marked by the album Mir nomer nol' ("The World Number Zero", Real Records 1999). During a talk show in 2000, Shevchuk defined this album as "a rather tough, alternative program; I called it a book, well, the 'book-destiny' of a man (...); the man dies, then he resurrects, acquires freedom. Mir nomer nol' is a whole show" (Nebudnii chas 2000: 03:3804.04). The album describes an imaginary journey from the "world number one" to a new world. The actuality of the end of the century adds an apocalyptic element to this musical project: the new millennium is the best time to rethink the past, and to begin a new life in order to find an exit out of the crisis. This idea of regeneration is close to the interpretation of the video of "Dozhd", to which a verse of "Rasstreliali rassvetami" ("Shot down with Dawns"), the ninth track of the album, probably refers: "It's not easy to tear out the memory, it's like to encourage rain with a song".

A more explicit and unambiguous quotation can be found in the first couplet of the first song of the album, "Odnorazovaia zhizn'" ("Disposable Life", or more literally "One Time Life"):

I got this role, but lost my ticket

We are killed by a game, in which there is nothing.

The literary critic Ol'ga Markelova explains this intertextual link:

In the well-known source of the self-quotation, the ticket is "lucky"; it is a component of the metaphor (the lucky ticket came up, because I got this role). In this case the relation is inverted: the role can be received at the cost of losing the (lucky) ticket. It raises the traditional topic of life as a game, but it is "a game, in which there is nothing", that is, in the last analysis, one more zero (Markelova 2001: 61).

The song "Odnorazovaia zhizn"' quotes "la poluchil etu rol"' to give it a new interpretation. A rock-poet's role has no meaning without the lucky ticket; he must find it again to ride out the post-Soviet crisis. At the beginning of the album there seems to be no way out of the world number one, but at the end of the journey to the world number zero the protagonist understands that he has to "carry out the role"; the line in Russian ("doigrat' rol'") rhymes with "mir nomer nol", a line repeated ad libitum in the last song of the album "Donesti $\sin ^{\prime \prime}$ ("Bringing the Blueness"). The next (and last) track of the album is an experimental collection of sounds named "Muzykal'nyi obraz, III" ("Musical Image - III"). It has the meaningful subtitle "Vykhod" ("The Exit"), a quite evident reference to "Outside the Wall", the last song of Pink Floyd's The Wall album (Harvest 1979), often cited as an obvious model for Mir nomer nol' (see Nebudnii chas 2000: 04.12). The intertextuality of the track is further complicated by quotations from Wagner, Tchaikovsky, Rachmaninoff and Mussorgsky (03.58-06.10).

In the concert version of Mir nomer nol', a big screen in the back of the stage helped to underline the nostalgic, self-reflective character of the album, showing images from different sources. The visual element was also present in the tour supporting DDT's next, double album Edinochestvo (a neologism mixing 'singleness' and 'loneliness', Real Records 2002-3). Some of the images scrolled through in the foreground are used in the video of "Mama eto - rok-n-roll" ("Mama, This is Rock'n'Roll"), probably the main and most famous song of the album, curiously released only in a live version. The video shows pictures of Viktor Tsoi, 
Aleksandr Bashlachev, and Maik Naumenko, three very famous Russian rockers who died in the late eighties-early nineties, and Nikita Zaitsev, the DDT's violinist who had passed away in 2000. The first images draw a link to the purity of the first rock, untouched by the nineties crisis, while the second can be interpreted as the symbol of DDT's role in this past. The refrain of the song, "Mama, this is rock \& roll / Rock it's me", point at Shevchuk's role and, at the same time, at the personal role of everyone who was or wants to be part of rock'n'roll.

Shevchuk, in a 2003 interview, describes Edinochestvo as an album "dedicated to the eighties-nineties rock movement" (Radke 2003: 260). The link to the past becomes even more evident here, thanks to self-quotations in the more proper sense of the word. In the video of "Osenniaia" ("Autumnal", 2002), the intertextuality with Shevchuk's autumnal songs is marked by scenes from the video of "Chto takoe osen'", discussed above. The two music videos follow the same structure, alternating images of Shevchuk in the present with other ones from the past. The contrast, present-past, is underlined by the use of black-and-white, followed more thoroughly in "Osenniaia" than in the video of the earlier song, particularly in the sequences 02.05-02.11, 02.31-02.43, and 02.54-03.07, where black-and-white pictures from "Chto takoe osen"" (with Shevchuk, Kinchev, and Butusov in the park) alternate with colored images of DDT's singer walking alone in a very similar park (in some frames from the older music video, the color is removed). If the Soviet rock movement was the hypertext of the video of "Chto takoe osen"", in "Osenniaia" we have a double hypertext, at the same time quoting the closer hypotext (the pictures in the park from the 1992 music video), and through it revealing the earlier hypotext.

In the second track of the same album we find a very sharp example of Shevchuk's self-quotations. The song has the same title as the 1985 track "Poet", to which it refers as its hypotext, and it has a similar subject (the poet-fighter). Two strophes of an untitled, earlier poem of Shevchuk's (5) are inserted into the song (Shevchuk 1999). The structure of the 2002 track "Poet" is as follows:

Verse I / Verse II / Verse III / Poem I / Verse IV / Verse V + Poem II

The first strophe of the poem is inserted between verses III and IV of the song, while the second one is recorded simultaneously with the last couplet (verse V), so that the words are hardly recognizable in the background. The two strophes quoted differ both musically and metrically from the rest of the song, the words being recited or, more exactly, shouted by the same Shevchuk to a different musical accompaniment. DDT also performs "Poet" in concert without the two quotations, which can be justified by technical reasons for the second part (the singer cannot sing two parts at the same time), but not for the first one. Therefore, this selfquotation can be considered also as a recontextualization of the poem, since it is only juxtaposed with the hypertext and does not fully take part in it.

The song "V boi" ("In the Struggle"), the second track on the next of DDT's albums, Propavshii bez vesti ("The Missing", Land Records 2005), is probably the most interesting case of musical palimpsest in DDT's discography, since the selfquotations involve music, words, and images. The hypotext is, again, the 1985 track "Poet", almost fully quoted inside the song (only one of the three strophes and the refrain are not included). The structure of the song is the following:

Part I: Instr. / V boi I / Refrain / V boi II / Refrain

Part II: Instr. / Poet I / Instr. (interrupted) / Refrain / Poet II 
Unlike the self-quotation in the 2002 version of "Poet", in this case the hypotext is an integral part of the song, present in all concert versions. The quotations appear in the second part of the song, where the hypotext is spaced out only by the refrain, without verses of "V boi". The song ends abruptly with the last lines of the hypotext. The effect is a progressive shift from the hypertext to the hypotext, which is confirmed by the musical analysis of the song.

The first half of " $\mathrm{V}$ boi" does not contain any quotations, and follows a familiar popular music structure: verse-refrain (2 times), introduced by two instrumental parts (the intro and the bridge) and followed by a short guitar solo. After the second refrain, the song changes quite suddenly, moving to a solo percussion section that introduces and accompanies the first part of the hypotext. The song repeats, word for word, the source of the quotation, and follows its rhythm, but the music is quite different. The verses of the 1985 version of "Poet" were performed almost as a rap on the same chord (Em), but very expressively, with lots of variations in intonation and alternating singing and reciting. In " $\mathrm{V}$ boi", the first half of the hypotext is recited monotonously, with no melody and no chords, including the final line, which in the 1985 version of "Poet" was sung on a different chord (B7), very loudly and an octave higher. This steady and monotonous singing, together with the use of percussion, gives this part of the song a ritual element. This effect is reinforced by the images of the music video, where Shevchuk performs a quite odd dance in the middle of a circle of light, with two hooded men playing a drum (video "V boi" 2005: 02:46-03:49). This synchronization of visual and musical elements emphasizes the evocation of the past, implicit in any self-quotation. After the end of the first part of the hypotext, the sound of a distorted guitar, together with other sounds and noises, joins the percussion. Before the end of the measure, the song is suddenly interrupted for 1-2 seconds (3:50-52), to leave space for the refrain. The second verse of "Poet" is sung almost the same way as the first, but the instruments go on playing, as in the accompaniment of "V boi": the hypotext runs into the hypertext and merges with it.

The lyrics of the song (the "V boi" part) add another element to the palimpsest:

Traces of the departed heroes

Were carried away by the spring surf.

They have not been near for a long time. (3 times)

Refrain: And I am engaged in battle! (4 times)

The "departed heroes" are the "missing" of the title of the album, the same ones as in the video of "Mama - eto rok-n-roll", who are "evoked" through the ritual of "V boi". The challenge to the old generation, in the last part of the self-quotation ("Look, old people, at anyone of these puppies, / He is swifter than you and more angry"), acquires a particular meaning in the hypertext, since the last verse, unlike the hypotext, is repeated three times and concludes the song. In the 1985 version of "Poet", Shevchuk himself was one of those "puppies", while in the hypertext (2005) the singer calls for the new generation to be "poet-fighters", like he and the "departed heroes" were in Soviet times.

Self-references and self-quotations are present also in DDT's later albums. In Prekrasnaia Liubov' (Navigator Records 2007), an album performed in a reflective, nostalgic style in a genre close to chanson, four tracks (including the eponymous one) are new arrangements of old songs, with small changes in the lyrics. "P. S.", the second part of the double album Inache (Otherwise, Navigator Records 2011), is also made of old songs, significantly accompanied by the date of composition, 
mostly quite recent (from 2001 to 2010), with the exception of the very last song ("Khich", 1985). In the album Prozrachnyi ("Transparent", Navigator Records 2014), the song "Zvezda" ("The Star") refers to a track in the album Propavshii bez vesti not only because it has the same title, but also through a quite explicit self-quotation ("night attack", repeated two times in the last lines of the two verses). The palimpsest is particularly apparent in the last of DDT's albums, Galia khodi ("Galia Go", Navigator Records 2018), the eponymous track referring to a very old song with the same title (the words of the refrain are also the same). "Zvezda-starukha" ("The StarOld Woman"), the fourth track of the album, is a medley of two songs, another "Zvezda" (the third one in DDT's discography) and a new version of a 1982 song of Shevchuk's. Significantly, the lyrics of the 2018 track "Galia, khodi" provide a new reflection on rock, with an interesting interpretative shift that I will not discuss in detail here, since it probably prepares a new period in DDT's history, not yet fully developed.

\section{Conclusions}

With his extremely long career, Yury Shevchuk is undoubtedly one of the most, if not the most, influential figures in Soviet and post-Soviet rock. However, the many changes in DDT's history are the result not only of the band's development but also, and probably mostly, of socio-cultural elements. As we have seen, in the first period, Shevchuk progressively increased his polemical attitude, prefiguring the rise of the second generation of Soviet rock (as in Kormil'tsev and Surova's reconstruction). DDT's sudden success in Saint Petersburg can be explained through Veselovsky's conception of "counter-flows" (see Mazzanti 2019: 23). The ground of the rock community of the capital was already prepared to accept Shevchuk's polemical approach, as if the counterculture was waiting for him, and ready to adapt his protest to its own inner socio-cultural exigences: a typical generational clash was reinterpreted in a political way. It is interesting to note that Shevchuk would later contest this interpretation, asserting that his band "has never been a social rock band, it is still another cliché" (see ORT 1995: 20,2-18). But the mythologization of rock in post-Soviet Russia went on very quickly, using DDT as one of the best examples of the label "russkii rok". The fourth period of Shevchuk's artistic development shows how he progressively accepted this role, trying at the same time to reinterpret it in a personal way. We can see clearly here how audience expectations and the author's reflection constantly interact and affect each other, creating a cultural product in which it is difficult to separate the individual and the social.

Intertextuality is a privileged instrument of this interaction between author and listener. We can apply to quotations in general what George Plasketes (2010: 2, 6) states about the practice of creating cover versions:

[It] may be viewed as a postmodern manifestation of rampant recontextualization in music as artists revisit, reinterpret and re-examine a significant cross section of musical styles, periods, genres, individual records and other artists and their catalogs of works. (...) [M] uch of the meaning and value in the cover song lies in its ability to bring listeners to new places and positions, and to make possible the broadening, deepening and enhancing of appreciative capacity. 
Intertextuality is not only about the past, but also and probably primarily about the present. As we have seen in Shevchuk's case, self-quotations can also be part of this dialogue between author and society, even if they are apparently only an author's inner monologue. DDT's singer uses self-quotations not only as a way to explain his "truth" about rock'n'roll, that is to create a reconstruction of a "lost home" that never existed (restorative nostalgia); they are also a way to reflect on the past from the point of view of the present (reflective nostalgia).

We can now come back to the question: to what extent is popular music inherently intertextual? We have mentioned some of the many examples of intertextuality in popular music, particularly present in some popular music genres. What we can say about the particular case of intertextuality analysed in this article? Shevchuk's self-quotations are only a particularly evident case of a practice quite widespread, even in the relatively narrow space of Russian rock: see for example Alexander Bashlachev (Gavrikov 2019) or the less famous but more straightforward case of Ermen Anti (Shostak 2014). At first glance, Burns and Lacasse's idea that "popular music is intertextual" (discussed above) seems to be unquestionable. However, as we have already stated, quotations are seemingly present in all music genres: music is intertextual, therefore it can be argued that popular music is intertextual because it is music, not because is popular. It can be also noted that examples of intertextuality are much easier to find in the most sophisticated examples of popular music (e.g. Frank Zappa, Shevchuk or Bashlachev), rather than in more simple cases (Britney Spears, Filipp Kirkorov or VIA Gra) (6): in the most popular cases, intertextuality is more occasional and less complex.

My definition, based on the opposition collective vs individual (see above, and, more in detail, Mazzanti 2019), can help to better characterize the role of selfquotations in popular music. My concept of popular music starts from the assumption that in highly individualized societies (the best example in chronological order being Western societies) there is no more space for fully folk music as the expression of the collectivity, since all music has become to some extent individual. 'Art music' and 'popular music' in this context can be interpreted as the two poles of the opposition, with infinite possible degrees: the authorial, individual element should be considered the 'artistic' part of popular music, while the collective element is associated with its 'folk' part. Self-quotations, being mostly an expression of the author's reflection, must be referred to the 'art element' of popular music. However the intuitive idea of popular music as a highly intertextual kind of music can be preserved, but in a different way.

Simon Frith underlines, in terms that might seem paradoxical, that there is a "difference between the music a composer writes (and a performer plays) and the music a listener hears" (1996: 63)." In support of this point, Frith cites American critic Barry Walters, stating that "[t] he meaning, the ultimate value, of pop emerges out of the meeting between music and listener, an interaction that changes over time" (ibid.: 84). I interpret this statement as the attitude of the listeners to appropriate musical products to express their own emotions and needs. Therefore, the reception of a song can be, and often is, different from the author's intent. Shevchuk's self-quotations are the product of his personal reflection, sometimes even a reaction to misinterpretations by listeners or journalists. With respect to this specific feature, they are an individual creation, that is, an expression of art music, rather than popular music. But DDT's songs are popular, since they are able to express collective cultural needs, even if the listeners' interpretations can contradict the author's aims. In Western societies, where individualization more or less strongly affects all people, and every composer is aware of their own authorship, popular music can be seen as the field of intersection between the individual and 
the collective, the personal and the social, in a constant dialogue between author and listener. Even self-quotations, by definition the most individual cases of intertextuality, can be "popularized" by the audience; they can hence be a way to reinterpret the past, simultaneously from the author's and from the listener's point of view.

\section{Endnotes}

(1) This article is an expanded version of a paper read at the 2007 biennial IASPM conference in Mexico City.

(2) The term appears more appropriate for a musical context, instead of "self-citation", which is mostly used when referring to academic studies (see Aksnes 2003), and "selfreference", which is more frequent in literary studies and is too generic for the cases I am discussing.

(3) With the exception of a track on the first album, all of DDT's songs have been written by the singer Yury Shevchuk, the only constant member of the band, the contribution of the rest of the band being limited to the arrangement. The name of the leader is perceived by the audience as a synonym of the band itself.

(4) All translations are mine unless otherwise noted.

(5) In Shevchuk's case, it is impossible to trace a clear line between poems and songs, since many of his songs were first composed as poems, and his poems are often recited in concert, almost like songs.

(6) Filipp Kirkorov, a Bulgarian pop singer and former husband of Alla Pugacheva, probably the most influential Soviet musical performer, still very influential in today's pop market; VIA Gra, an Ukrainian girl group.

\section{References}

\section{Bibliography}

Aksnes, Dag W. A macro study of self-citation. Scientometrics, vol. 56, N² (2003): 235-246.

Arbuzov, M. 1985. Kogda sryvaetsia maska. Leninets, Ufa, 13 apr. http://sovr.narod.ru/articles/85002.html Accessed 31 aug. 2018.

Banerji, A. 2008. Writing History in the Soviet Union. Making the Past Work. New Delhi.

Boym, S. 2001. The Future of Nostalgia. New York: Basic Books.

Burns, L. and Lacasse, S. 2018. The Pop Palimpsest: Intertextuality in Recorded Popular Music. Ann Arbor: University of Michigan Press.

Chion, M. 2016. Sound: An Acoulogical Treatise. Durham: Duke University Press.

Dolgov, A. 2002. DDT. Ponimanie svobody. FUZZ, 1. <https://web.archive.org/web/20141024050205/http://fuzzmagazine.ru/magazine/2002/1-02/1036-ddt- Accessed 31 Aug. 2008.

Domansky Yu.V. 2013. Rok-poeziia: perspektivy izucheniia. Russkaia rok-poeziia: tekst i kontekst 14. Tver': 7-36.

Frith, S. 1996. Performing Rites: On the Value of Popular Music. Cambridge, Mass: Harvard University Press. 
Gavrikov V. A. 2019. Rannii Bashlachev - pozdnii Bashlachev: zaimstvovanie motivno-siuzhetnykh matrits i avtotsitatsiia. Russkaia rok-poeziia: tekst $i$ kontekst 19. Tver': 148-55.

Genette, G. 1997. Palimpsests: literature in the second degree. Lincoln: University of Nebraska Press.

Kharitonov, N. Imperiia DDT. Moskva: Vagrius.

Kormil'tsev, I. and Surova O. 1998. Rok-poeziia v russkoi kul'ture: vozniknovenie, bytovanie, evoliutsiia. Russkaia rok-poeziia: tekst i kontekst 1. Tver': 5-33.

Kozitskaia, E. A. 2001. Sub'iazyki i subkul'tury russkogo roka. Russkaia rokpoeziia: tekst $i$ kontekst 5. Tver': 169-189.

Laffranchi, A. 2002. "Don't stop": autocitazioni dei Rolling Stones. Corriere della sera, 20 Nov: 40.

Markelova, O. A. 2001. "la ne znaiu kak zhit', esli smert' stanet vdrug nevozmozhna...": dvoemirie i vremia v al'bome lu. Shevchuka "Mir nomer nol'". Russkaia rok-poeziia: tekst i kontekst 5. Tver': 59-69.

Mazzanti, S. -

2007. Il concetto di 'russkij rok' tra storia e mito. In Cifariello, A., and Cadeddu, C. Ed., Percorsi della memoria (testo arti metodologia ricerca). Roma: Universita Tor Vergata, 2007: 281-300. https://www.academia.edu/32454361/Mazzanti 2007 II concetto di Russk ij_rok.doc

2011. La "svolta" della nuova cultura sovietica nelle canzoni rock della perestrojka. In D'Amico, T. (Ed.) A vent'anni dalla caduta del muro di Berlino. Napoli: Universita "L'Orientale": 37-51.

https://www.academia.edu/33129343/La_svolta_della_nuova_cultura_soviet ica nelle canzoni rock della perestrojka

2014. The Live Album or Many Ways of Representing Performance. Muzikologija, 17: 69-86.

https://www.academia.edu/15577535/The live album or many ways of re presenting_performance

2019. Defining popular music: Towards a "historical melodics". M. Dumnić Vilotijević and I. Medić (Ed.), Contemporary Popular Music Studies, Systematische Musikwissenschaft: 17-26.

Mikhailova, V. A. 2000. Tema poeta i poezii v tvorchestve luria Shevchuka. Russkaia rok-poeziia: tekst i kontekst 4, Tver': 109-113.

Middleton, R. 1990. Studying Popular Music. Philadelphia: Open University Press.

Plasketes, G. 2010. Play It Again: Cover Songs in Popular Music. Burlington: Ashgate.

Polupanov, V. K. 2003. Kinchev: "Populiarnost" - eto cheshuia. Argumenty $i$ fakty. 52 (1209), 24 Dec. http://www.aif.ru/archive/1630596 Accessed 31 Aug. 2018.

Radke, E. 2003. Interv'iu Evelin Radke s luriem Shevchukom. Russkaia rokpoeziia: tekst i kontekst 7. Tver': 257-260.

Risch, W. J. ed., 2015. Youth and Rock in the Soviet Bloc: Youth Cultures, Music, and the State in Russia and Eastern Europe. Lanham, MD: Lexington Books.

Ryback T. W. 1990. Rock around the bloc. Oxford. 
Schieder, M. 2000. lazyk russkogo roka. Russkaia rok-poeziia: tekst i kontekst. 4. Tver': 102-108.

Shevchuk Y. 1999. Zaschitniki Troi. Saint Petersburg: Petropol'.

Shostak G.V. 2014. Ermen Anti i russkii rok vtoroi poloviny 1980-kh: tsitaty i avtotsitaty. Russkaia rok-poeziia: tekst $i$ kontekst 15. Tver': 281-91.

Smirnov I. 1994. Vremia kolokol'chikov. Zhizn' i smert' russkogo roka. Moscow: INTO.

Steinholt, Y. B. 2005. Rock in the Reservation: Songs from the Leningrad Rock Club 1981-86. Larchmont: MMMSP.

Troitsky A. 1987. Back in the USSR: the True Story of Rock in Russia. London.

Vernallis C. 2004. Experiencing music video: aesthetics and cultural context. Columbia University Press.

Veselovsky A. N. 2006. Izbrannoe: Istoricheskaia poetika. Moscow: Rossnep. Yurchak, A. -

2003. Soviet Hegemony of Form: Everything Was Forever, Until It Was No

More. Comparative Studies in Society and History, 3 (45), July: 480-510.

2005. Everything Was Forever Until It Was No More: The Last Soviet

Generation. Princeton: Princeton University Press.

Williams, J. A. 2013. Rhymin' and Stealin'. Musical borrowing in hip-hop. University of Michigan.

\section{Web Sources}

Austin, M., and Tayeb, M. 2004. Berlioz and his music: self-borrowings. The Hector Berlioz's website. http:/www.hberlioz.com/Works/borrowings.htm Accessed 31 Aug. 2018.

Glass Onion. Beatles Bible. https://www.beatlesbible.com/songs/glass-onion/ Accessed 29 Sep. 2019.

Howell, C. 1997. Stanford and Musical Quotation. MusicWeb International. http://www.musicwebinternational.com/classrev/2003/oct03/Stanford_Quotation.htm Accessed 31 Aug 2018.

Kazan' 2006. Press-conference. http://www.ddtmsk.503.com1.ru/programs/press_conf_15_12_06_kazan.wmv Accessed 31 Aug. 2008.

RUsskii PORtal. Kurs dollara k rubliu i rublia k dollaru s 1792 po 2018 gody. https://pynop.com/kurs.htm Accessed 31 Aug. 2018.

russmuss.net/song/3669 - "la poluchil etu rol" ("I Got this Role")

russmus.net/song/3728 - "Poet"

Shishov, R. 1989. DDT - voprosov vsegda bol'she, chem otvetov.

Komsomol'skaia pravda. Pul's, 8.

< http://www.ddtworld.spb.ru/wds/articles.shtml Accessed 31 Aug. 2008.

\section{Discography}

Alisa (1993), Dlia Tekh, Kto Svalilsia s Luny, Moroz Records, Russia Beatles, The (1967), "All You Need Is Love", Parlophone, 7 July, UK Beatles, The (1968), "Glass Onion", Apple, 22 November, UK

Brigada S (1993), Reki, FeeLee Records

Chai-f (1993), Deti Gor, SNC, Russia 
DDT -

(1982), Svin'ya na raduge, DDT Records, 1996 (unofficial release 1982), Russia (1983), Kompromiss, DDT Records, 1997 (unofficial release 1983), Russia (1984), Periferiia, DDT Records, 1996 (unofficial release 1984), Russia (1985), Vremia, DDT Records, 1997 (unofficial release 1985), Russia (1989), la Poluchil Etu Rol', Melodia, Russia

(1992), Aktrisa Vesna, DDT Records, Russia

(1993), Chernyi Pes Peterburg, DDT Records, Russia

(1995), Eto Vse, DDT Records, Russia

(1997), Rozhdennyi v SSSR, DDT Records, Russia

(1999), Mir Nomer Nol', REAL Records, Russia

(2002-3), Edinochestvo I-II, REAL Records, Russia

(2005), Propavshii bez vesti, CD Land Records, Russia

(2007), Prekrasnaia Liubov', Navigator Records, Russia

(2011), Inache/P.S., Navigator Records, Russia

(2014), Prozrachnyi, Navigator Records, Russia

(2018), Galia Khodi, Navigator Records, Russia

Nautilus Pompilius (1996), "Russkii Rok", Kryl'ya, Apex Records, January, Russia

Pink Floyd (1979), "Outside the Wall", The Wall, Harvest, 30 November, UK

Queen (1991), "The Show Must Go On", Parlophone, 14 October, UK

Rolling Stones, The (2002), "Don't Stop", Rolling Stones/Virgin, 30 September, UK

\section{Videography}

ORT. 1995. Chas pik, 09 October, http://staroetv.su/video/vip/26799/ort_pervyj_kanal/chas pik_ort 09101995 jurij_shevchuk_vedushhij_dmitrij_kiseljov Accessed 31 Aug. 2018.

Nebudnii chas. 2000. Omsk, 15 april. https://novom.ru/en/watch/df5spmdlh7k Accessed 31 Aug. 2018.

Interviews

Evgenii, Personal communication. Moscow, October 2000. 